\title{
THE IMPORTANCE OF THE STATE ENSURING THE RIGHT OF CITIZENS TO QUALITY MEDICAL CARE IN THE CONTEXT OF THE VACCINATION OF COVID-19
}

\author{
Olena Artemenko', Lubov Krupnova², Liudmyla Kurylo ${ }^{3}$ \\ Svitlana Kovalova ${ }^{4}$, Liliia Kniazka ${ }^{5}$
}

\begin{abstract}
The article analyzes the state guarantee of citizens' right to quality medical care in terms of vaccination against COVID-19. It has been established that in modern conditions it is extremely important to ensure the proper functioning of health care, the provision of quality medical services, which, in turn, will guarantee proper medical care. At the time when the world has already entered the stage of eradicating coronavirus disease, through mass vaccination, the role of state regulation of these activities increases significantly. The state must provide Ukrainian citizens not only with vaccines, but also with reliable information about the need for vaccination. It turns out that the small number of vaccinated people in Ukraine is not only due to the slow pace of procurement and vaccination, but also to the lack of awareness of citizens about all the benefits of the need for vaccination. The main vaccination rates in the world and Ukraine as of mid-April 2021 have been determined. It is concluded that the positive in today's conditions are: the efforts of the legislator still not to influence the subjective choice of every resident of Ukraine on the need for vaccination; regulatory support of the Center for Public Health, which in turn will strengthen the network of regional Centers for Disease Control and Prevention (CDC); creation of a Roadmap for the introduction of a vaccine against acute respiratory disease COVID-19 caused by the coronavirus SARS-CoV-2. At the same time, negative aspects remain: public ignorance of the importance of vaccination, the slow pace of vaccination, and delays in approving the necessary vaccine doses, which in turn undermine the authority of the state and its bodies in the context of human rights to quality health care. Proposals are made to focus the attention of public authorities and local governments on the information component of ensuring the right of citizens to quality health care in the context of vaccination against COVID-19.
\end{abstract}

Key words: citizens, legal culture, medical care, COVID-19, state authorities.

JEL Classification: I11, I19

\section{Introduction}

With the world gripped by a global health crisis and the World Health Organization (WHO) declaring a pandemic due to the spread of the COVID-19 coronavirus infection, human rights are becoming a priority.
It should be noted that states impose certain restrictions on certain human rights in order to protect public health in the context of the COVID-19 coronavirus pandemic. Only in Ukraine, during the second year of the fight against coronavirus infection, the Ukrainian government introduced

\footnotetext{
Corresponding author:

${ }^{1}$ National University of Life and Environmental Sciences of Ukraine, Ukraine.

E-mail: artolena11@ukr.net

ORCID: https://orcid.org/0000-0003-2041-8925

${ }^{2}$ Private Higher Education Establishment

"Academician Stepan Demianchuk International University of Economics and Humanities", Ukraine.

E-mail: zakhist@ukr.net

ORCID: https://orcid.org/0000-0003-1789-0647

${ }^{3}$ National University of Kyiv-Mohyla Academy, Ukraine.

E-mail: kurylo.l@gmail.com

ORCID: https://orcid.org/0000-0001-5131-0146

${ }^{4}$ National University of Life and Environmental Sciences of Ukraine, Ukraine.

E-mail: kovalyeva@gmail.com

ORCID: https://orcid.org/0000-0002-7617-3595

${ }^{5}$ State Fiscal Service University of Ukraine, Ukraine.

E-mail: knyazka@ukr.net

ORCID: https://orcid.org/0000-0003-0357-2680
} 
several blockages. It should be recognized that such actions did help to contain the spread of the virus for some time. At the same time, such restrictions must comply with generally accepted standards in the field of human rights. It is worth noting that the relevant issue is the formation of the level of legal culture of compliance with social regulations and awareness of socially significant positive behavior of citizens in relation to other members of the community. Even the imposed blockages in Ukraine have not reduced the dynamics of reducing the total number of patients with coronavirus infection COVID-19 for the period 2019-2021.

At the same time, EU countries show a dynamic in decreasing the total number of patients compared to the pandemic years for the period 2019-2021. EU citizens behave consciously toward other members of society. Examples include keeping a distance when in a public place and wearing a mask.

At a time when the world has already entered the stage of mass vaccination, the role of government provision of not only vaccines, but also of informing citizens about the importance of combating COVID-19 coronavirus infection in this way is increasing.

Due to the fact that Ukraine is not purchasing the first vaccines and the fact that a certain portion of its citizens have received the first doses of the vaccine, there is a need to explore such state support regarding the right to adequate medical care in the process of vaccination against COVID-19.

Therefore, the purpose of the work is to study the state provision of the right of citizens to quality health care in the context of vaccination against COVID-19.

An analysis of recent studies and publications shows that scholars and researchers are very interested in ensuring human rights in the context of COVID-19. scientific value and relevance. At the same time, some aspects of our study were covered in the works of the following scientists: V.M. Lekhan, D.V. Karamishev, J.F. Radish, N.M. Udovichenko, L.V. Domnikov and others.

\section{Aim and tasks}

The purpose of the study is to establish and analyze: - the duty of the state to create conditions in Ukraine aimed at protecting human life and health;

- the current state of state support for the realization of the right of citizens to quality medical care in terms of vaccination from COVID-19;

- ensuring the right and existence of the choice of types of vaccine against coronavirus infection COVID-19;

- coverage of the formation of consciousness and legal culture of citizens in the context of compliance with the rules of sanitary and epidemiological measures aimed at combating coronavirus infection COVID-19.

The study analyzes the content of public administration, examines the vector of management measures to form the administrative apparatus of health care management, the use of preventive measures and penalties for violations of sanitary and epidemiological measures to control COVID-19 coronavirus infection in public places, as well as suspension from work.

The following tasks are determined depending on the goal:

- describe the administrative and legal measures to combat coronavirus infection COVID-19;

- focus of public authorities and local governments on the information component of ensuring the right of citizens to quality medical care in the context of vaccination against COVID-19;

- to pay attention to the information component of ensuring the right of citizens to quality health care in the context of vaccination against COVID-19 and establishing the role of public authorities and local government;

- to determine the state of legal culture of citizens in the context of vaccination and compliance with the rules of sanitary and epidemiological measures aimed at combating COVID-19 coronavirus infection.

\section{Presentation of the main material}

To begin with, it is worth noting the basic legal norms directly related to health care for citizens, as well as the role of the state in this process.

According to Art. 49 of the Constitution of Ukraine "Everyone has the right to health care, medical assistance and medical insurance". In addition, paragraph 3 of this article stipulates that "The state creates conditions for effective and accessible medical care for all citizens. In state and municipal health care facilities, medical care is provided free of charge; the existing network of such establishments cannot be reduced. The state promotes the development of medical institutions of all forms of ownership" (Constitution of Ukraine).

Article 3 of the Law of Ukraine "Fundamentals of Health Care Legislation of Ukraine" defines medical assistance as "the activity of health care institutions, rehabilitation institutions, departments, units and individuals - entrepreneurs, registered and licensed in the manner prescribed by law, in the field of health care, which is not necessarily limited to medical care and/or rehabilitation assistance, but directly related to their provision" (Law of Ukraine № 2801-XII).

Protection of human life and health is recognized as one of the priorities of public policy (Lytvyn, Artemenko, 2021). Guarantees of human and civil rights and freedoms are a system of specific means 
by which citizens realize the effective exercise of their rights and freedoms, their protection, and their defense in the event of violation. Their main purpose is to provide everyone with equal legal opportunities to acquire, exercise, protect and defend subjective rights and freedoms (Gusareva, Tikhomirova, 2017).

Thus, guarantees of human rights and freedoms are the totality of all factors in the economic, political, state, cultural, and other spheres that contribute to the full realization of his rights. The right to health care and the proper provision of medical services and care is inherent to a person from birth, is realized every day, is protected by the state and has a system of protection of the violated right.

Karamishev D.V. determined that the most pronounced objective factors in the low level of health of citizens, and thus in the efficiency of the industry and the quality of health care, are primarily the lack of awareness among citizens about the opportunities available in their health care system and the threats that arise. Low trust in medical facilities, non-compliance with safety, hygiene and sanitation rules were the main factors affecting human health and life. Today, due to the large-scale coverage of the planet by viral infection, society needs a significant transformation of the culture of behavior and awareness of the consequences of violations of preventive measures (Karamishev, 2007).

Given the pandemic impact on society, it can be stated that new factors are emerging that affect the increase in the total number of patients with coronavirus infection COVID-19. Such factors include:

- first, the low level of timely access to the necessary assistance to health facilities;

- second, violation of the basic rules of hygiene and anti-epidemic measures: distance, mask mode;

- third, due to the lack of real control by the state over the preservation of health in society;

- fourth, the lack of actual control over the observance of anti-epidemic rules by citizens in public places.

According to Karamishev D.V., the state measures to be envisaged should be very simple - the promotion of the ideology of a healthy lifestyle, employment control, and medical examinations. Thus, state policy in the field of health care should be aimed at ensuring the high priority of health in the system of social values of society, to promote the attention of each person to their own health (Karamishev, 2007).

What is important for our study, based on the scientist's position, is that indeed the citizens of Ukraine do not have a proper level of awareness of the capabilities of the health care system, which is extremely important when vaccinating Ukrainian citizens against the COVID-19 coronavirus infection.

The right to health care is one of the most important social human rights, which is enshrined not only in the regulations of Ukraine, but also in international acts, namely: human rights instruments of the UN, WHO, ILO and resolutions of international forums. The right to health is also regulated in the Universal Declaration of Human Rights, the Convention on Human Rights, the Convention on the Elimination of All Forms of Discrimination against Women and others. It is also worth noting that it belongs to the group of economic, social and cultural rights that fall under the rights of the second generation.

It is noted that today the main lever of influence on the formation of medical services belongs to such state body, the central body of executive power - the Ministry of Health of Ukraine. In addition, its subdivisions specialized in quality control of medical services are represented by the Department of Medical Services, the Medical Department, the Department of Licensing and Quality Control of Medical Services, the Department of Emergency and Disaster Medicine (Artemenko, Lytvyn, 2021).

The right to health care is one of the most important social human rights, which is enshrined not only in the regulations of Ukraine, but also in international acts, namely: human rights instruments of the UN, $\mathrm{WHO}, \mathrm{ILO}$ and resolutions of international forums. The right to health is also regulated by the Universal Declaration of Human Rights, the Convention on Human Rights, the Convention on the Elimination of All Forms of Discrimination against Women, and others. It is also worth noting that it belongs to the group of economic, social and cultural rights, which are second-generation rights.

In order to fully ensure the opportunity for everyone to exercise this constitutional right, certain levers or tools are needed from the state, represented by its bodies. One such mechanism is the institution of service provision, in particular medical services, the formation of which to a certain extent depends on the subjects of state administration (Artemenko, Lytvyn, 2021).

Today, the main health care institution responsible for preserving and strengthening the health of citizens is the Public Health Center of the Ministry of Health of Ukraine (CGH). In addition to the above, the state institution has the authority to carry out social and hygienic monitoring of diseases, epidemiological surveillance and biological safety, group and population prevention of diseases, control of epidemics and strategic management in the field of public health. The state institution was established to implement the order of the Cabinet of Ministers of Ukraine by the Order of the Ministry of Health of Ukraine dated 18.09.2015 № 604.

The main task of the Center for Public Health is to work in the field of public health. The center performs treatment-and-prophylactic, scientificpractical and organizational-methodical functions 
in the field of health care in order to ensure the quality of treatment of patients with socially dangerous diseases, in particular from coronavirus infection COVID-19. CGC participates in the formation of regulatory policy and interacts with other ministries, research institutions, international and nongovernmental organizations working in the field of public health and combating socially dangerous diseases. Based on the topic of the research topic, it can be noted that starting from its own vision, the state institution "Public Health Center of the Ministry of Health of Ukraine" should be a national leader in forming a culture of health among citizens of Ukraine.

Being on guard to strengthen, preserve and protect the health of the citizens of Ukraine CGS within the professional community through continuous training, development and improvement of the educational professional environment, developing professional and educational standards.

Protecting the right to inform the citizens of Ukraine, the Center provides reliable data on the sick. Promotes rules of conduct that include the status of epidemic measures.

Of course, in cooperation with public authorities and local governments, to overcome the dynamic increase in the number of patients and encourage citizens to vaccinate, the CPC forms the evidence base for the preparation of management decisions and regulations, which today must be operational and dynamic, as flexibility and speed of public response directly affects the stable sanitary and edematous state of citizens (Public Health Center of the Ministry of Health of Ukraine).

It should be noted that on February 4, the Verkhovna Rada of Ukraine adopted in first reading the Draft Law № 4142 "On the health care system". The bill is the result of joint work during the last 3 years of the expert community and international partners ( $\mathrm{WHO}$, EU, USAID). This bill aims to create a full-fledged national epidemiological service. In fact, the Center for Public Health will be strengthened by a network of regional Centers for Disease Control and Prevention (CDC). TsGZ, will be the main expert institution, which will be responsible for coordinating the activities of this network in the framework of epidemiological surveillance and response to hazards. CDCs will be set up around regional facilities laboratory centers, regional public health centers, statistics and monitoring and evaluation units. These centers will be fully responsible for their own region - from routine monitoring of indicators to forecasting, detection of emergencies, outbreaks and response to them (Draft Law of Ukraine № 4142).

First of all, what should be emphasized, based on the provisions of the aforementioned draft law, is the norm concerning mandatory vaccination against coronavirus infection. It should be noted that the majority of citizens of Ukraine are not supporters of such compulsory vaccination. And their actions can be explained on the basis that people do not want to be vaccinated against what the state imposes on them, so the chairman of the Committee on National Health, Medical Services and Health Insurance Mykhailo Radutsky said that the bill was passed in the first reading, and in preparation for the second reading the section on vaccinations will be excluded. Therefore, the issue of vaccination in Ukraine will continue to be regulated by current legislation (Radutsky, 2021).

This seems quite acceptable, because it is impossible to force a person to do something against his will, which has been repeatedly emphasized in international conventions, pacts and, above all, in the Constitution of Ukraine.

At the same time, if we turn to the case law of the European Court of Human Rights (ECHR), especially since its decision is a source of law for our country, it is possible to cite the following theses.

In Pretty v. United Kingdom (No. 2346/02) it was stated that in the provision of medical care, even when the refusal of a certain method of treatment could be fatal, forced medical treatment without the consent of an adult legally capable patient constituted an interference with his right to physical integrity and a violation of the rights guaranteed by Article 8 of the European Convention (Pretty v. United Kingdom, 2002).

The ECHR also noted that in order to preserve the sense of freedom to refuse treatment, it is necessary for the patient to have the right to make decisions in accordance with his or her own views and values, no matter how irrational, unreasonable and shortsighted they may seem to others (case № 302/02). But in paragraphs 85 and 136 of the decision, the court stated that the state has an interest in protecting and preserving the life and health of its citizens. In certain cases, these interests will prevail over a citizen's right to self-determination. The state can require citizens to undergo medical procedures to address the threat of harm to citizens' health (Pretty v. The United Kingdom, 2002).

Thus, based on the topic of our study, if we are talking about eliminating the threat of harm to the health of citizens of Ukraine (in conditions of COVID-19 it is especially relevant), the state must ensure an appropriate level of quality of medical care, including vaccination of its citizens.

It is known that as of mid-April 2021, three vaccines have already been imported into Ukraine from various manufacturers in the global community. Without going into what these vaccines are, what their origin or manufacturer is, here's just the number. The first vaccine received 500,000 doses, the second vaccine 215,000 doses, and 367,000 were received more recently. The total number of vaccines imported 
is just over 1 million, whereas according to official data of the State Statistics Service of Ukraine, as of March 1, 2021 there were 41.5 million citizens of Ukraine (Official data, 2021).

Thus, it can be said that Ukraine cannot boast of a high rate of vaccine procurement, including the pace of vaccination of Ukrainian citizens, because as of mid-April 2021 just over half a million Ukrainian citizens received only the first dose of the vaccine (by the way - it is planned that the human immune system will be able to resist the virus only after the second dose) and several people the second dose.

According to official data from the Ministry of Health of Ukraine, vaccination against COVID-19 started in Ukraine on February 24, 2021. A total of $20,950,877$ vaccinations were administered from the start of the campaign until November 1, 2021. The number of persons vaccinated against COVID-19 received one dose, a total of $12,228,642$ persons, received two doses, a total of $8,722,235$ persons, which is $21.9 \%$ of all Ukrainian citizens (Coronavirus Vaccination Statistics (COVID-19, 2021).

If to compare the level of vaccination in Ukraine with European countries, it is possible to draw the following statistics. Comparing in the percentage of citizens: Ukraine $1.22 \%$, UK $48.78 \%$, Israel $58.43 \%$, Malta 45.62\%, UAE 50.89\%, Hungary $36.40 \%$, France $20.29 \%$, Chile $40.78 \%$, Sweden $19.81 \%$, Uzbekistan 1.35\%, Japan 1.32\%, Turkey $15.04 \%$, Poland 19.33\%, Canada 26 , 79\% (Coronavirus Vaccination Statistics (COVID-19, 2021).

Such indicators of vaccination in Ukraine indicate not only a rather slow pace of procurement and implementation of vaccination among citizens, but also the lack of awareness of citizens about all the advantages and necessity of such vaccination. It should be noted that it is primarily the duty of the state to provide citizens with information about: the importance and necessity of vaccination; the number of imported vaccines; the advantages and disadvantages of this or that type of vaccine. It is equally important to carry out explanatory work among the citizens of Ukraine, to form the concept of medical literacy and awareness in the minds of everyone, to ensure the right of everyone to quality medical care.

Regarding informing the citizens of Ukraine about vaccination, it is worth mentioning in the scope of our study such a legislative act as the Order of the Ministry of Health of Ukraine "On approval of the Roadmap for the introduction of vaccine against acute respiratory disease COVID-19 caused by coronavirus SARS-CoV-2, and mass vaccination in response to the COVID-19 pandemic in Ukraine in 2021-2022" (Order of the Ministry of Health of Ukraine № 3018).
It should be noted that this Order should become an information act for citizens of Ukraine. Which should contain the following information:

- regarding available vaccines;

- studies on each type of vaccine;

- the ability of each type of vaccine to counteract coronavirus infection;

- possible consequences for humans after receiving each dose of the vaccine.

After all, his introduction contains the following thesis: "Roadmap for introduction of vaccine against acute respiratory disease COVID-19 caused by SARS-CoV-2 coronavirus and mass vaccination in response to pandemic coronavirus COVID-19 disease in Ukraine (hereinafter - Roadmap) was developed to ensure adequate and equal access to effective vaccine against acute respiratory disease COVID-19 caused by SARS-CoV-2 coronavirus (hereinafter referred to as COVID-19 coronavirus disease) for all citizens of Ukraine who should receive it, as well as to control related processes" (Order of the Ministry of Health of Ukraine № 3018).

However, when analyzing this regulatory act, in terms of its compliance with the expectations that every average citizen would like to see, we should note its imperfection, as indicated by the Chief Sanitary Doctor of Ukraine - it is necessary to completely revise the roadmap for vaccination against coronavirus, as the task is to vaccinate $70 \%$ of adult citizens by the end of 2021 (Lyashko, 2021). But based on the rate of vaccination and the number of vaccines, in our opinion, it will be extremely difficult.

According to V.M. Lehan, the state through the executive authorities, local governments or other bodies authorized by it should perform the functions of organizing medical care and financial reimbursement of medical services, ensuring the realization of expectations, rights and legitimate interests of all groups of health care and balance between them. At the same time, it should also take care of ensuring control over expenditures and rational use of public financial resources allocated to the health sector (Lehan, 2015).

Agreeing with the position of V.M. Lehan, it can be said that the state, represented by the authorized bodies of state power and local self-government is obliged to take responsibility for creating appropriate conditions for medical care of citizens associated with the free choice of a particular type of vaccine, to ensure the expectations, rights and legitimate interests of all groups of participants in the health care system and the balance between them.

Given the state's current realities of ensuring the nation's health, state agencies have begun to take the following steps.

First, a number of restrictions were developed and implemented by the protocol of the Standing 
Committee on Technogenic and Ecological Safety and Emergencies dated 28.10.2021 № 68, such as:

- only those with a negative PCR test or antigen test within 72 hours will be able to use public transportation. And a certificate of vaccination with one or two doses. It is also possible to use public transportation with a certificate of convalescence;

- the obligation to check whether passengers have vaccination certification documents is incumbent on both the driver and special groups of law enforcement agencies. Checks are carried out selectively, not at stops, but directly in the transport;

- it is prohibited to be without masks covering the nose and mouth in the underpasses, at bus stops, on the territory of health care and educational institutions.

In other places of common use it is possible to be without a mask only on condition of social distance in one meter.

According to article 12 of the Law of Ukraine "On protection of citizens against infectious diseases" and article 27 of the Law of Ukraine "On ensuring the sanitary and epidemiological welfare of citizens", employees of certain professions, industries and organizations whose activities may lead to infection of these workers and the spread of infectious diseases are subject to compulsory preventive vaccination also against other relevant infectious diseases.

The Ministry of Health, by its order on approval of the List of professions, industries and organizations, whose employees are subject to mandatory preventive vaccination, included in the list of professions subject to mandatory vaccination against COVID-19, employees of: the central executive authorities and their territorial bodies; local state administrations and their structural subdivisions; institutions of higher, postgraduate, professional higher, professional (vocational), general secondary, including special, preschool, out-of-school education, institutions of special education and scientific institutions, regardless of type and form of ownership (Order of the Ministry of Health of Ukraine № 2153).

In case of refusal or evasion of mandatory preventive vaccinations, these workers are suspended from performing these types of work (Article 12 of the Law of Ukraine "On Protection of Citizens from Infectious Diseases").

But it should be noted that vaccination is mandatory in the absence of absolute contraindications to preventive vaccinations, according to the List of medical contraindications and warnings to preventive vaccinations, approved by the order of the Ministry of Health of Ukraine from 16.09.2011 № 595, registered in the Ministry Justice of Ukraine 10.10.2011 for № $1161 / 19899$ (as amended by the order of the Ministry of Health of Ukraine dated 11.10.2019 № 2070).
The Ministry of Justice of Ukraine concluded that Order of the Ministry of Health № 2153 complies with the Convention for the Protection of Human Rights and Fundamental Freedoms, in particular Article 8 of the Convention on the right to respect for private and family life, and the case law of the European Court of Human Rights.

Thus, if the question of compulsory vaccination of employees from the above list is raised in the above order, it can be concluded that it cannot be done only by those employees who have absolute contraindications to preventive vaccination. The list of medical contraindications and warnings for vaccination against COVID-19 is explained by the Ministry of Health of Ukraine.

Contraindications to vaccination can be determined by the family or treating physician and an appropriate opinion on temporary or permanent contraindications. If additional information about the verification of the diagnosis, the course of the disease, or the need for additional examinations is needed, the doctor may also refer the patient to a specialist, after which he or she will finally decide whether to vaccinate or postpone it until a certain time.

If a patient has a contraindication to one of the COVID-19 vaccines, he or she should be vaccinated with other types of vaccines if possible.

In the future, it will be possible to enter a second dose contraindication or a general contraindication to vaccination in the electronic health system.

In addition, there are contraindications to the introduction of certain vaccines, such as CoronaVac from Sinovac Biotech is contraindicated in pregnant women. If there are questions about choosing a vaccine, talk to the family physician.

Recall that antibody testing or other laboratory tests are not required before vaccination with COVID-19.

Thus, in particular, in accordance with the Resolution of the Cabinet of Ministers of Ukraine № 1236 (as amended), it is the heads of state bodies (public service), heads of enterprises, institutions and organizations must ensure:

1) control of compulsory preventive vaccinations against COVID-19 by employees and civil servants, whose compulsory preventive vaccinations are provided by the list of professions, industries and organizations, whose employees are subject to compulsory preventive vaccinations, approved by Order No. 2153 of the Ministry of Health of October 4, 2021;

2) dismissal of employees and civil servants, the obligation of preventive vaccinations against COVID-19 which is listed and who refuse or evade such mandatory preventive vaccinations against COVID-19 in accordance with Article 46 of the Code of Laws on work of Ukraine, part two of 
Article 12 of the Law of Ukraine "On Protection of Citizens from Infectious Diseases" and part three of Article 5 of the Law of Ukraine "On Civil Service", except for those who have absolute contraindications to such preventive vaccinations against COVID-19 and provided a medical opinion about the presence of contraindications to vaccination against COVID-19, issued by a health care institution;

3) taking note that:

- at the time of such removal, remuneration of employees and civil servants is carried out taking into account part one of Article 94 of the Labor Code of Ukraine, part one of Article 1 of the Law of Ukraine "On Remuneration" and part three of Article 5 of the Law of Ukraine "On Civil Service";

- removal of employees and civil servants is carried out by issuing an order or directive of the head of a state body (civil service) or enterprise, institution, organization with its obligatory notification to the persons being removed;

- the period of suspension is set until the causes that caused it are eliminated.

It should be noted that there is no definition of "dismissal" in the legislation of Ukraine, so there are some difficulties in how to do it correctly.

It is necessary to proceed first of all from the fact that in practice dismissal means suspension of labor relations (temporary release of the employee from the obligation to perform work under the concluded employment contract and, in turn, temporary release of the employer from the obligation to provide the employee with work or create conditions for its implementation and, accordingly, to pay wages.

It is important to understand that the temporary removal of an employee from duty by way of dismissal (on the conditions and grounds established by law) is not a disciplinary sanction in itself, but a special preventive measure. This measure is applied in exceptional cases and is aimed at preventing and/or preventing negative consequences. Dismissal in this case does not necessarily entail the termination of the employment relationship. The employee's job is kept for the period of dismissal.

As a general rule, dismissal of an employee is carried out by the employer on the grounds provided by law on its own initiative (such grounds, including those listed in the above laws and the Cabinet of Ministers Resolution № 1236).

Removal from work is made out by the order (order) of the employer. It should state the basis and terms of dismissal.

The employee must read such an order immediately under the list, as it concerns the exercise of the employee's right to work.

Given that the dismissal order will not specify the specific period of dismissal, it is necessary after the removal of all the grounds that caused such dismissal, to issue an order of admission to work.

It is advisable to inform the dismissed workers about the consequences of such a temporary measure. There are several of them.

- In case of dismissal of the employee with termination of salary payment, temporary disability allowance is not granted (Article 22 of the Law of Ukraine "On Compulsory State Social Insurance" provides that temporary disability allowance is granted to the insured person as full or partial compensation, which he loses due to illness or other insured events). During the period of dismissal without pay, social insurance contributions are not paid, and such a period is not included in the insurance record.

- According to Article 82 of the Labor Code, Article 9 of the Law of Ukraine "On vacation", the period of dismissal of an employee does not count in the length of service, which gives the right to annual leave.

The employer should also pay attention to the provisions of Article 44-3 of the Code of Administrative Offenses of Ukraine "Violation of the rules on quarantine of people", which stipulates that violation of the rules on quarantine of people, sanitary and hygienic, sanitary and anti-epidemic rules and norms of the Law of Ukraine protection of citizens from infectious diseases", other acts of legislation, as well as decisions of local governments on combating infectious diseases - entails the imposition of a fine on citizens from one to two thousand non-taxable minimum incomes and officials - from two to ten thousands of tax-free minimum incomes.

Employees have the right to go to court to resolve labor disputes, regardless of the nature of the work performed or the position held, except in cases provided for by law (Article 2 of the Labor Code). According to the explanations of the Plenum of the Supreme Court of Ukraine, set out in paragraph 10 of the Resolution of 24.12.1999 № 13 "On judicial practice of labor legislation," if it is found that in violation of Article 46 of the Labour Code of Ukraine the employer has suspended an employee from work with suspension of wages, the court must satisfy the claim of the latter in this part on the recovery of average earnings for the period of enforced idleness (Article 235 of the Labor Code). Violators are brought to justice for violating labor legislation in accordance with the law (Plenum Resolution № 13).

\section{Conclusions and suggestions}

The study conducted a detailed analysis of the current state of state support for the implementation of the right of citizens to quality health care in the 
field of vaccination from COVID-19. It turns out that despite the fact that Ukraine is fighting for the crown for the third year in a row, no single approach causes such an infection.

Among the positives are: the legislator's efforts not to influence every Ukrainian citizen's subjective choice about the need for vaccination; regulatory support from the Center for Public Health, which in turn will strengthen the network of regional Centers for Disease Control and Prevention (CDC); the creation of a roadmap for the introduction of the vaccine against acute respiratory disease COVID-19, caused by the coronavirus SARS-CoV-2.

At the same time, negative aspects remain the lack of public awareness of the importance of vaccination, the slow pace of vaccination, and delays in approving the necessary vaccine doses, which in turn undermines the credibility of the state and its bodies in the context of human rights to quality health care.

Therefore, at present, state authorities and local governments should pay attention to the information component of ensuring the right of citizens to quality health care.

\section{References:}

The Constitution of Ukraine: the law of Ukraine of June 28, 1996 № 254k/96-VR. Available at: https://zakon.rada.gov.ua/laws/show/254\%D0\%BA/96-\%D0\%B2\%D1\%80\#Text

Fundamentals of the legislation of Ukraine on health care: Law of Ukraine of 19.11.1992 № 2801-XII. Available at: https://zakon.rada.gov.ua/laws/show/2801-12\#Text

Lytvyn, N. A., \& Artemenko, O. V. (2021). Protecting human rights in the context of the COVID-19 pandemic, taking into account the gender component. Pravo.ua, № 1, pp. 50-56.

Theory of state and law. textbook manual; for general ed. S. D. Gusareva, O. D. Tikhomirova. Kyiv: NAVS, Education of Ukraine, 2017.320 p.

Karamishev, D. V. (2007). Problems of providing constitutional guarantees and implementation of state health policy in Ukraine. mater. And All-Ukrainian scientific practice. conf. (April 19-20, 2007, Lviv). LOBF "Medicine and Law", p. 157.

On the public health system: draft law of Ukraine dated 22.09.2020 № 4142. Available at: http://w1.c1.rada.gov.ua/ pls/zweb2/webproc4_1?pf3511=70025

Public Health Center of the Ministry of Health of Ukraine. Available at: https://phc.org.ua/pro-centr

Vaccination in Ukraine will be voluntary - Mykhailo Radutsky on the bill № 4142. Available at: https://sluga-narodu.com/vaktsynatsiia-v-ukraini-bude-dobrovilnoiu-mykhaylo-radutskyy-pro-zakonoproiekt-4142/

Pretty v. The United Kingdom: judgment of the European Court of Human Rights (Case № 2346/02) of 29 April 2002. Available at: https://zakon.rada.gov.ua/laws/show/980_210\#Text

Number of citizens as of March 1, 2021. Official data of the State Statistics Service of Ukraine. Available at: http://www.ukrstat.gov.ua/

Statistics of vaccination against coronavirus (COVID-19). Available at: https://index.minfin.com.ua/en/ reference/coronavirus/vaccination/

On approval of the Roadmap for the introduction of the vaccine against acute respiratory disease COVID-19 caused by the coronavirus SARS-CoV-2, and mass vaccination in response to the pandemic COVID-19 in Ukraine in 2021-2022: order of the Ministry of Health Of Ukraine from 24.12.2020 № 3018. Available at: https://zakon.rada.gov.ua/rada/show/v3018282-20\#Text

Ukraine should make 47 million vaccinations by the end of 2021. Available at: https://www.slovoidilo.ua/ 2021/04/12/novyna/suspilstvo/ukrayina-povynna-zrobyty-47-mln-vakcynaczij-kincya-2021-roku-lyashko

Lekhan, V. M., Slabky, G. O., \& Shevchenko, M. V. (2015). Analysis of the results of reforming the health care system in the pilot regions: positive consequences, problems and possible ways to solve them. Ukraine. The health of the nation, vol. 3, pp. 67-86.

Order of the Ministry of Health of Ukraine dated 04.10.2021 № 2153 "On approval of the List of professions, industries and organizations whose employees are subject to mandatory preventive vaccination". Available at: https://moz.gov.ua/article/ministry-mandates/nakaz-moz-ukraini-vid-04102021--2153-pro-zatverdzhennjapereliku-profesij-virobnictv-ta-organizacij-pracivniki-jakih-pidljagajut-obovjazkovim-prophylactic-scheplennjam

Artemenko, O. V., \& Lytvyn, N. A. (2021). Providing the population with public medical services as a guarantee of the realization of the constitutional right to health care. Legal scientific electronic journal, vol. 3, pp. 157-159. Available at: http://lsej.org.ua/index.php/arkhiv-nomeriv?id=135

Resolution of the Plenum of the Supreme Court of Ukraine of 24.12.1999 № 13 "On the practice of application by courts of legislation on remuneration of labor". 